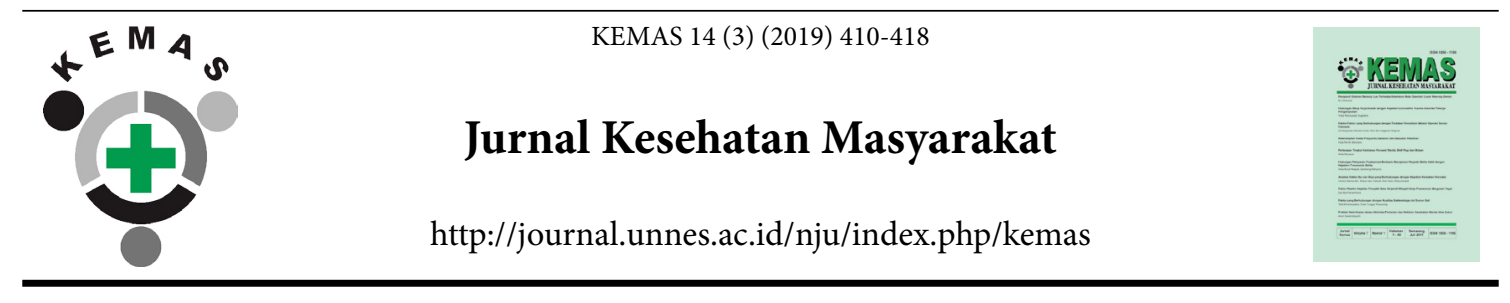

\title{
Evaluation Study of Health Promotion Hospital (HPH) in Muhammadiyah Hospital in DKI Jakarta, Indonesia
}

\author{
Emma Rachmawati Tatang ${ }^{1 凶}$, Tri Mawartinah ${ }^{1}$ \\ ${ }^{1}$ Faculty of Health Studies of Universitas Muhammadiyah Prof DR HAMKA (UHAMKA), Indonesia
}

\begin{tabular}{l} 
Article Info \\
\hline Article History: \\
Submitted October 2018 \\
Accepted February 2019 \\
Published March 2019 \\
\hline Keywords: \\
Evaluation, Health \\
Promotion, Hospital \\
\hline DOI \\
https://doi.org/10.15294/ \\
kemas.v14i3.16520
\end{tabular}

\begin{abstract}
Health Promotion in Hospital (HPH) initiatives still run slowly. This study aimed to evaluate the implementation of HPH at Muhammadiyah Hospital in Jakarta, Indonesia. The survey was carried out during March-April 2018 to 304 permanent employees in three Muhammadiyah Hospitals in Jakarta. Measurements include employee characteristics and self-assessment tools related to the achievement of HPH national standards. According to HPH activities, the results showed that the average knowledge of employees was good enough (5.6; max: 10) and good attitudes (29.6, max: 40), but low HPH activities $(25.3 \%)$, and low involvement in HPH training (13.5\%). The highest achievement was the "partnership" standard (68\%), and the lowest achievement was "reviewing the needs of the hospital community" (50\%). There were $56 \%$ of respondents stating the achievement of the HPH national standard in Muhammadiyah Hospital was good. The results of this study as evidence-based to design the priority of HPH improvement strategies in Muhammadiyah Hospital.
\end{abstract}

\section{Introduction}

Health Promotion in Hospital (HPH) aims to give a high quality and comprehensive medical services and treatment implemented through health promotion activities to patients, hospital staff and society in general as part of identity and routine practices of hospital. By implementing $\mathrm{HPH}$, it means that a hospital is integrating promotional effort and health education, prophylaxis, and rehabilitation services in a curative services (WHO, 2004). WHO has $5 \mathrm{HPH}$ standard which has been used by many countries in implementing $\mathrm{HPH}$. In Indonesia, the standard has been adopted and developed by Ministry of Health and is being used to create its own HPH standard consisting of 6 standards: (1) Management Policy, (2) Assessment of Hospital Community Needs,
(3) Hospital Community Empowerment, (4) Hospital implements Community Development to support Empowerment, (5) Partnership, (6) Hospital manifests a healthy workplace (Kemenkes RI, 2011),

Health promotion efforts are not an easy task to do for hospital, especially related to its role to have more contribution in health of society, which is far from its essence of responsibility to give health services in the form of curative services or clinical services (Johansson et al., 2009). Hospitals are expected to have reorientation on its formal structure and routine activities to be more concerned in promoting health, even if in reality, a systemic reorientation still has a very limited efforts (Wieczorek et al., 2015), and still has a specific concern about creating an appropriate design 
to its promotion program so it would be a comprehensive program and not just a shortterm project (Pelikan, 2012). At the other hand, hospital as a complex health institution which is run and directed by many professionals and high-qualified person, faces difficulties when creating health promotion programs, strategies and approach to which it would be fit and proper in daily operation (Johannson et al., 2009). The fact shows that there are still professional health personnel that has incapability in identifying health promotion on their daily role which could lead to unnecessary debate, misunderstanding and constraint in developing health promotion program. The reluctance of professional health personnel to integrate health promotion are being indicated as main constraint in implementing health promotion in hospital (Lee et al., 2015; Lee, Chen, \& Wang, 2014; Whitehead, 2004). An unclear strategy and tools for implementation are being other reason (Groene, 2005).

Other factors that influence the implementation of $\mathrm{HPH}$ are Hospital Ownership, accreditation status of the hospital, HPH Policy and Plan, the amount of hospital staff that actively participate in $\mathrm{HPH}$ training activities, hospital's self-identification to overall organization effectiveness in HPH (Lin \& Lin, 2011); hospital's status and its HPH networking also its size (Groene et al., 2010). Other study in hospital in Indonesia found that $\mathrm{HPH}$ program timing and coordination with other sectors, limited human resources in HPH Unit, unsocialized of $\mathrm{HPH}$ standard and instructions has also became the factors that influence the implementation of HPH (Nova et al., 2016). Hakim, BZ, \& Fauzi (2013) also mentioned factors such as HPH implementation team that has not had specific training about $\mathrm{HPH}$ implementation, promotion program creating process that does not involve patients in assessing the needs of a proper and needed health promotion for patient also would influence the $\mathrm{HPH}$ implementation.

On national scale, $\mathrm{HPH}$ program has already had legal foundation in the form of Regulation of Ministry of Health of Republic Indonesia of 2012 Number 004 about HPH technical guidance which make it mandatory to implement $\mathrm{HPH}$ in every hospital in
Indonesia, including Muhammadiyah Hospital (RSM). But after all, as mentioned before, the implementation of the program is slow. The implementation of $\mathrm{HPH}$ in Indonesia for 15 years has not shown significant result and the program sustainability has not been well maintained, depending on the commitment of the hospital. Some of the strategic issues of $\mathrm{HPH}$ implementation has appeared in major hospitals in Indonesia, such as (1) Hospital has not been implementing $\mathrm{HPH}$ as one of main policy in creating health service standard, (2) Hospital has not yet gave patients information about prevention and curation acts related to their diseases, (3) Hospital has not embodied as a safe, clean, healthy workplace, and (4) hospital has a very limited partnership program with other parties to create a preventive and promotive services (Kemenkes RI, 2011).

As part of government efforts to increase the quality of $\mathrm{HPH}$ program and implementation in hospitals in Indonesia, in 2011, Indonesias Ministry of Health ordered Directorate of Health Promotion and Society Empowerment to partner with Pimpinan Pusat Muhammadiyah to enhance the implementation of $\mathrm{HPH}$ in Muhammadiyah Hospitals (RSM) in every cities there is RSM such as Yogyakarta, Makassar, DKI Jakarta, Bandung, Palangkaraya, Tegal, Bumiayu, Palembang, North Sumatera, Padang, Kendal, and all cities in East Java. The partnership is still being implemented until 2018 and years ahead. HPH partnership in RSM has resulted in positive impacts for Management commitment, patient, and society in every RSM region. But on the other hand, until present, there are no comprehensive evaluation taken to evaluate $\mathrm{HPH}$ standard failure and achievements which is important to indicate $\mathrm{HPH}$ program effectiveness and Al Islam Muhammadiyah value which would be main characteristic of $\mathrm{HPH}$ in RSM. From those reason, this research is important as an evidence based research to highlight evaluation of HPH policy in general and specifically HPH in RSM.

\section{Methods}

This research is a quantitative study with cross-sectional design. Sample taken was 304 of permanent employee of 3 RSM in DKI Jakarta which was sampled randomly 
and proportionally from a total population of 1486 people. Respondent exclusion criteria is permanent employee that was having annual leave or having sick permission during survey. Survey has been conducted in March-April 2018. RSM involved in this research is type $B$ general hospital which is spread in 3 Jakarta region, that is RS Islam Jakarta (RSIJ) Pondok Kopi (East Jakarta), RSIJ Sukapura (Central Jakarta), RSIJ Cempaka Putih (North Jakarta).

Instrument used in this research was questionnaire about respondents characteristics (Education level, activity level in HPH and participation in $\mathrm{HPH}$ training), $\mathrm{HPH}$ knowledge (value $\alpha$-Cronbach > 0.449: quite reliable) with categories of answer right or wrong; attitude (value $\alpha$-Cronbach > 0.840: very reliable) with categories of answer strongly agree, agree, disagree, strongly disagree; and self-assessment tool about 6 achievements of HPH standard from Indonesia's Ministry of Health of 2011 with achievement categories not achieved, partly achieved, and achieved, with additional indicator of the implementation of Al Islam Muhammadiyah value in every HPH standard (value $\alpha$-Cronbach $>0.9$ : very reliable). Final achievement value in every standard would be divided in to 2 categories, good ( $\geq$ median value) and less good (< median).

Data analysis is descriptive univariate analysis to calculate $\alpha$-Cronbach value from instruments statistics value (mean, median, SD, range), percentage/proportion, also to show frequency/characteristic distribution of each variables which is provided in the form of table.

\section{Results and Discussion}

The results of respondent's HPH activities and training in hospital distribution table based on education level classification could be seen at table 1. It could be seen that most of respondents which are permanent employee in 3 RSM have Diploma degree (72\%), and some respondents claimed that they have been involved in HPH activities (25.3\%) and have had HPH training (13.5\%). Especially in RSIJ Pondok Kopi, there are only 2 respondents (1.9\%) that have had $\mathrm{HPH}$ training and 11 respondents $(10,6 \%)$ have been involved in HPH activities. It became a very important notes for both RSM or HPH team in 3 mentioned RSM because the amount of employee that actively involves in $\mathrm{HPH}$ training could act as a strengthening point for relations among HPH condition, hospital characteristic, and hospital's self-identification to overall organization effectiveness in $\mathrm{HPH}$ (Lin \& Lin, 2011). On the other hand, even though RSIJ Sukapura have not had HPH partnership program, it could exposes its better and deeper involvement in $\mathrm{HPH}$ compared to 2 other RSM. Low rate of employee's involvement on both HPH training and activities is in line with several studies which found that there are still a less-reliable HPH employee, training, funding, and physical facilities in hospitals which then became an obstacle for employees to promote $\mathrm{HPH}$ in hospital and lead to

Table 1: Respondent's Characteristics Distribution

\begin{tabular}{lllll}
\hline Variable Name & \multicolumn{3}{l}{ Score (\%) } & \\
\cline { 2 - 5 } & $\begin{array}{l}\text { RSIJ CP* } \\
(\mathrm{n}=105)\end{array}$ & $\begin{array}{l}\text { RSIJPK } \\
(\mathrm{n}=104)\end{array}$ & $\begin{array}{l}\mathrm{RSIJ} \mathrm{SP}^{\star} \\
(\mathrm{n}=95)\end{array}$ & $\begin{array}{l}\text { Total } \\
(\mathrm{n}-304)\end{array}$ \\
\hline $\begin{array}{l}\text { Education Level } \\
\text { High School }\end{array}$ & - & $7(6.70)$ & $15(15.8)$ & $22(7.2)$ \\
D3 & $94(89.5)$ & $72(69.3)$ & $53(55.8)$ & $219(72.0)$ \\
S1 & $11(10.5)$ & $25(24.0)$ & $25(26.3)$ & $61(29.1)$ \\
S2 & - & - & $2(2.1)$ & $2(0.7)$ \\
Involved in HPH activities & $29(27.6)$ & $11(10.6)$ & $37(38.9)$ & $77(25.3)$ \\
Involved in HPH training & $21(20.0)$ & $2(1.9)$ & $18(18.9)$ & $41(13.5)$ \\
Hospital has partnership & Yes & No & No & - \\
\hline
\end{tabular}

Source: Primary Data

${ }^{*}$ Note: RS CP: RSIJ Cempaka putih; RSIJ PK: RSI Pondok Kopi; RSIJ SP: RSI Sukapura 
inability of employee's understanding of the HPH framework (McHugh et al., 2010).

Table 2 shows that for variable HPH knowledge, the average scores are about equal in each RSM that is 5.59 and quite homogenous $(\mathrm{SD}=0.92)$. The scores however could not be said as a good one yet because the best score is 10 , while average scores about the level of HPH understanding is $55.9 \%$. Low rate of knowledge scores could happen because HPH minimum campaign and socialization delivered to each RSM staffs, staff's low curiosity about HPH which could be because they have already had a fixed schedule and activities for each day, also the commitment of the hospital's management which have not yet put HPH as a priority to be implemented in their hospital. Either hospital that has already had HPH partnership with Ministry of Health of Indonesia or the one whom has not had the partnership yet, the score for HPH knowledge is slightly different.

For variable respondent's attitude towards HPH, the average scores show a good score about 29.57 with high variety of score. If compared to maximum score recorded, that is 40 , and the average value of 29.7 , it marked a good attitude towards HPH with $74.25 \%$. Same with previous variable, averages scores between hospital that has had partnership with Ministry of Health of Indonesia and the one whom has not, show a slight difference.

Knowledge and attitude towards HPH show that the clearance, well understanding and shared views are vital and became fundamental aspects that need to be fulfilled to implement and develop health program for society. The result of this research also marks that there is a different approach that has been adopted in promoting health based on professional health personnel's perception on health promotion and strategy to enhance health promotion on their daily activity (Johansson, et al., 2009).
It shows that not all professional health personnel have capabilities in identifying their role in promoting health which could be a latent constraint for future health promotion development.

Based on respondent's answer regarding to $\mathrm{HPH}$, there is still misconception that $\mathrm{HPH}$ goal is to get the hospital an award because it has done health promotion while the true goal is not as simple as what they might thought. Based on HPH guidance of 2011 from Ministry of Health of Indonesia, health promotion activity mainly settled to create healthy and clean lifestyle and behavior (PHBS) which is relevant or even could catalyst rehabilitation and curation process of people with disease. At the other hand, there is also information from other study mentioned that there is a difficulty faced by health personnel in relating their role as a professional health personnel with a role as a health promoter. To this case, the ability of understanding and being aware of health promotion potential in any case need to be enhanced so that health personnel could make the goal of HPH in line with their roles and activities (Johansson et al., 2009). In short, professional health personnel in RSM are now being challenged to enhance their capabilities, knowledge and new competency about HPH. The health promotion in hospital, also indirectly urge hospital personnel to have a healthy lifestyle and behavior and being role model both for their colleagues and society (Lin \& Lin, 2011). HPH could be used to decrease morbidity and mortality number, increase hospital's revenue, decrease medical expenses, increase both internal and external stakeholders satisfaction, prevent the spread of non-communicable disease, and enhance quality of life (Yaghoubi \& Javadi, 2013).

For details of attitudinal variables, it can be seen that the majority of respondents/

Table 2: Distribution of Statistical Values for Knowledge Variables and Respondents' Attitudes about HPH in RSM in DKI Jakarta in 2018

\begin{tabular}{lllllllllllllll}
\hline \multirow{1}{*}{ Variable } & \multicolumn{3}{c}{ RSIJ CP } & \multicolumn{4}{c}{ RSIJ PK } & \multicolumn{4}{c}{ RSIJ SP } & \multicolumn{4}{c}{ Combination } \\
\cline { 2 - 15 } & Mean & Md & SD & Mean & Md & SD & Mean & Md & SD & Mean & Md & SD \\
1. Knowledges about HPH & 5.4 & 6 & 0.8 & 5.7 & 6 & 0.9 & 5.6 & 6,0 & 0.94 & 5.59 & 6.0 & 0.92 \\
2. Attitude towards HPH & 29.5 & 29 & 2.8 & 29.9 & 30 & 2.9 & 30.31 & 30 & 4.41 & 29.57 & 29 & 3.49 \\
\hline
\end{tabular}


permanent staff of RSM express their attitudes agreeing that HPH is related to positive things, which are: not burdensome to their duties, is not carried out parallel/together with medical services/clinics, is not adequately handled by special health promotion personnel only, it must be implemented, it needs to involve the community, and special studies are needed. However, more than $80 \%$ of respondents expressed an inappropriate attitude towards the following matters related to $\mathrm{HPH}$, namely: not being able to guarantee a safe, healthy and clean workplace, not necessarily reflecting Islamic values, and no need to implement ideals of Muhammadiyah movement. This group of people could be included in the "demarcater" group, which is a group of health personnel who explicitly separate health promotion efforts, but for some things they actually behave as health promotion workers (Johansson et al, 2009).

In table 3 we can see a complete picture of the scoring of the achievement of each standard (standard 1 to 6) according to the 2011 Ministry of Health's HPH guidelines which were added to the Muhammadiyah standard Islamic values (AIK) that must be applied in each RSM, and the HPH standards achievement scoring value for the three combined RSM. Based on the results of self assessment data processing related to the achievement of HPH implementation, the highest average score on all standards was achieved by RSIJ Sukapura (84.7\%) compared to the average score in the other two RSM (59.6\% and $65.1 \%$ ) and combined average (75.1\%). Although this hospital has not been exposed to the HPH partnership program between MPKU PP Muhammadiyah and the Director General of Health Promotion of the Republic of Indonesia Ministry of Health which has been going on since 2011, most of the respondents rated that all HPH standards has been achieved.

RSIJ Pondok Kopi, which also has not been exposed to the HPH partnership program, obtain the lowest average score on all standards achievement compared to the other two RSM and the combined average score. Whereas RSIJ Cempaka Putih obtained a mean score below the average RSIJ Sukapura score but above the average score of RSIJ Pondok Kopi on all standards, but only on the standard achievement standard 1 (Management Policy) (77.7\%) and standard 2 (Assessment of Hospital Community Needs) (75.7\%) it exceeds the combined average of achievement (73.9\%).

After grouping based on the median value on each standard, the information obtained shows the proportion of respondents whose level of achievement considered as

Table 3. Statistical Distribution of HPH Standards Achievement in Muhammadiyah Hospital in DKI Jakarta, 2018

\begin{tabular}{|c|c|c|c|c|c|c|c|c|c|}
\hline \multirow{2}{*}{$\begin{array}{l}\text { Achievement } \\
\text { Criteria }\end{array}$} & \multicolumn{2}{|c|}{$\begin{array}{c}\text { RSIJ Cempaka } \\
\text { Putih }\end{array}$} & \multicolumn{2}{|c|}{ RSIJ Pondok Kopi } & \multicolumn{2}{|c|}{ RSIJ Sukapura } & \multicolumn{3}{|c|}{ Combined score (3 RSM) } \\
\hline & $\begin{array}{l}\text { Mean } \\
\text { Median }\end{array}$ & SD & $\begin{array}{l}\text { Mean } \\
\text { Median }\end{array}$ & $\mathrm{SD}$ & $\begin{array}{l}\text { Mean } \\
\text { Median }\end{array}$ & $\mathrm{SD}$ & $\begin{array}{l}\text { Mean } \\
\text { Median }\end{array}$ & SD & Min/Max \\
\hline \multirow[t]{2}{*}{ Standard 1} & 17.10 & 3.98 & 13.62 & 5.47 & 18.97 & 3.67 & 16.49 & 4.98 & $0 / 22$ \\
\hline & 18.00 & & 13.00 & & 21.00 & & 17.0 & & \\
\hline \multirow[t]{2}{*}{ Standard 2} & 7.57 & 2.67 & 6.50 & 2.45 & 8.17 & 1.94 & 7.39 & 2.28 & $0 / 10$ \\
\hline & 8.00 & & 6.00 & & 9.00 & & 8.00 & & \\
\hline \multirow[t]{2}{*}{ Standard 3} & 7.18 & 2.32 & 6.99 & 2.55 & 8.62 & 1.87 & 7.57 & 2.39 & $0 / 10$ \\
\hline & 7.00 & & 7.50 & & 10.00 & & 8.00 & & \\
\hline \multirow[t]{2}{*}{ Standard 4} & 7.27 & 2.32 & 6.42 & 2.58 & 8.22 & 1.93 & 7.28 & 2.42 & $0 / 10$ \\
\hline & 7.00 & & 5.5 & & 10.00 & & 7.00 & & \\
\hline \multirow[t]{2}{*}{ Standard 5} & 7.23 & 2.16 & 6.95 & 2.48 & 8.14 & 1.82 & 7.42 & 2.28 & $0 / 10$ \\
\hline & 7.00 & & 7.00 & & 9.00 & & 7.00 & & \\
\hline \multirow[t]{2}{*}{ Standard 6} & 7.85 & 2.25 & 2.45 & 2.06 & 8.96 & 1.59 & 7.92 & 2.38 & $0 / 10$ \\
\hline & 9.00 & & 2.0 & & 10.00 & & 9.00 & & \\
\hline Standards & 46.85 & 7.88 & 42.94 & 0.01 & 61.07 & 11.19 & 54.07 & 14.59 & $0 / 72$ \\
\hline Total (1 to 6$)$ & 47.0 & & 40.0 & & 66.00 & & 55.0 & & \\
\hline
\end{tabular}


good in each HPH standard in the three RSM ranged from $50 \%$ to $68 \%$, with details as follows: Standard 1 (Management Policy): 55\%. Standard 2 (Assessment of Hospital Community Needs): 50\%. Standard 3 (Hospital Community Empowerment): 56\%. Standard 4 (Hospital implements Community Development to support Empowerment): 62\%. Standard 5 (Partnership): 68\%. Standard 6 (Hospital manifests a healthy workplace): $56 \%$.

For standard 1 (Management Policy), the results of this study indicated that respondents considered that in all three RSM the achievements were not good enough in increasing HPH management capacity (less than $46.7 \%)$. In one RSM that is known not to have a $\mathrm{HPH}$ unit, almost all standard 1 indicators were assessed as low in achievement, with the lowest score being in "Hospital socialize HPH in the entire hospital range" (23.1\%). The highest achievement is in the indicator "Hospital applies Muhammadiyah standard Islamic values in implementing $\mathrm{HPH}$ activities" in RSIJ Sukapura (85.3\%).

Health promotion efforts in health services, including hospitals, can only be applied if supported by internal structure and culture and policy supports that is relevant politically and environmentally and willing to change for innovation. For this reason, reorientation of health services related to $\mathrm{HPH}$ requires appropriate resources and frameworks that enable the achievement of HPH as an integrated part of an organization and become "core business", not just "side issues," but must be included as part of culture, direction and strategy of the hospital. This requires the support of high-level policy makers to encourage change (VHA, 2009). From the same source, the VHA (Victorian Health Association) states that if health promotion is limited only to special divisions/sections, or departments or even staff, HPH is still an activity that is marginalized and does not challenge the entire organization to reorient the role of the hospital in the community or making health promotion integrated into the broader role of hospital staff. The structure of health services is an important component in giving a signal about commitment to organizational development and for showing staff about the importance of health promotion.
VHA also quoted that health services/hospitals are effectively health-oriented health services, then strategic leadership at the government and executive level is very necessary, and then equipped with a system that is suitable for the empowerment and education of health care staff/hospitals.

In the latest first edition of the National Hospital Accreditation Standard (SNARS) (effective as of January 1st 2018), which is a reference for the quality of health services provided by hospitals in Indonesia, this health promotion effort has not been explicitly stated, but efforts such as prevention of diseases such as hand washing programs or PHBS activities (Healthy and Clean Life Behavior) or Germas (Healthy Community Movement) which is an issue in health promotion in the community mentioned as part of the hospital accreditation assessment. Because the HPH is still managed by units or even staff assigned specifically, it is possible that $\mathrm{HPH}$ is still a less challenging activity, a side issue, marginalized, not yet integrated and has not become a strong commitment from the hospital leadership, including at RSM.

For the achievement of standard 2, which is "Assessment of Hospital Community Needs" which has the lowest level of achievement in RSM (50\%), the indicator "Hospital studies the information needs and appropriate communication media needs of patients, visitors, and the community around the hospital" does look low (26\% to 67.4\%). The aim of achieving standard 2 is to obtain an overview of the information needed by patients, families of patients, visitors and the community around the hospital as a basis for implementing Health Promotion. For activities such as "peoplecentered care" and "healing environments" as part of health promotion in hospitals or other health services based on the analysis of patient, family, visitor and community needs around the hospital are important. Research shows that such forms of activity can in fact provide a positive influence on patients, reduce stress and accelerate physical healing. The strength of the coherence/integration of the needs of all parties is a key factor in facilitating the introduction of health promotion in health services (Dilani, 2008). This deficiency can also be found in other 
hospitals where assessment of promotional needs for patients still seems unilateral without involving patients more deeply to assess the need for appropriate and beneficial health promotion for patients (Hakim et al., 2013).

Furthermore, the results of the study showed that there were $56 \%$ of respondents who stated that Standard 3 (Hospital Community Empowerment) had been achieved. The highest achievement indicators are in the indicator "Hospital mandates staffs to implement Islamic values in empowering the community while serving in curative, rehabilitative, preventive, and promotive aspects" for RSIJ Sukapura, but the indicator "Hospital mandates hospital staff to empower the community while serving in curative, rehabilitative, preventive, and promotive aspects is still a low average level of achievement (49.3\%). Important hospital community empowerment is assessed/ measured because both nationally and globally, HPH is expressed as "expanding the hospital's public health role", in relation to local communities and their social and health services which will optimize networking among providers, users and community leaders in the health sector and society as a whole (Amiri et al., 2016; Whitehead, 2005). In the course of the $\mathrm{HPH}$ partnership in RSM, empowerment of the community and RSM target groups related to national and local health priority issues in the RSM region became the main objective of HPH implementation both inside and outside the building. This is in accordance with the objectives of standard 3 implementation, namely increasing the power and participation of the hospital community in preventing and/ or overcoming the health problems it faces (Kemenkes RI, 2011).

In achieving Standard 4 (Hospital implements Community Development to support Empowerment), there are 62\% of respondents who stated that they were achieved well, but some indicators still showed lowest achievement in the three RSM namely "Hospital utilizes individuals/groups outside the hospital together with Muhammadiyah's charity efforts to develop the atmosphere $(52.8 \%)$ "and" the Hospital used the mass media to develop the atmosphere "for the achievement in RSIJ Cempaka Putih (36.2\%). This is of course quite unfortunate given that Muhammadiyah as the owner of RSM throughout Indonesia is the second largest community organization in Indonesia that has leadership/management and charity health, social and educational efforts at the central, regional, branch and sub-branch levels whose numbers are spread throughout the Indonesian territory. This opportunity seems to have not been optimized by RSM in DKI Jakarta in coordinating well for $\mathrm{HPH}$ activities in their respective locations.

The health promotion approach in hospitals leads to the context/setting where people live, work and play, because the approach/location approach at the initial stage is a very interesting and feasible route that will help the organization's actions for the success of health promotion efforts (Poland et al., 2009). This is reflected in the implementation of the $\mathrm{HPH}$ at the RSM in Indonesia in the form of health promotion activities that are prioritized to create clean and healthy behavior (PHBS) and Germas activities, so this is in accordance with the settings at the initial stage and is very feasible and interesting to achieve together through the involvement of individuals/groups or Muhammadiyah business charities around the RSM location. In the HPH partnership activity report between the Directorate General of Health Promotion and Community Empowerment of the Indonesian Ministry of Health and MPKU PP Muhammadiyah, there are many opportunities that have been used together so that the HPH partnership program can run well and continue until present. Although in the development of the $\mathrm{HPH}$ to date there have been many significant changes that can affect the implementation and development of $\mathrm{HPH}$, among others, the internal conditions of RSM management, limited funds and high competition, quality and efficiency are important for innovative approaches in $\mathrm{HPH}$.

To realize the full potential of the HPH approach, which means improving the health of patients, staff and the community, $\mathrm{HPH}$ must be applied not only to projects such as this partnership program, but a comprehensive approach, integrated in the hospital health service management system, which includes: commitment, resources, communication, 
action plans, evaluation, education, research, sustainability, and networking (Baxter et al., 2008).

To achieve Standard 5 (Partnership) with an overall achievement rate of $68 \%$, the highest achievement is in the indicator "Hospital prioritizes the principle of Al Islam in establishing partnerships with any sector related to the implementation of health promotion" and "Hospital has a partnership network with other hospitals and Muhammadiyah health charities business in the implementation of health promotion "(above 80\%). However, partnerships with other non-Muhammadiyah parties/networks (other sectors, businesses and other private sectors) are still low (average proportion of $52.7 \%$ ).

Partnerships or networks in $\mathrm{HPH}$ efforts at all levels (local, regional, national and international) are very important to improve the achievement of $\mathrm{HPH}$ performance and improve the quality of HPH efforts. Partnership or training in $\mathrm{HPH}$ is a very valuable supporting mechanism and an intervention tool that is useful for organizational development (Baxter et al., 2008), because a good form of partnership can help overcome obstacles in the hospital such as funding constraints, human resources, methods of delivery, monitoring and evaluation, as well as other matters related to $\mathrm{HPH}$ development efforts.

The results of the study for the achievement of Standard 6 (Hospital manifests a healthy workplace) were stated to still be considered low by some RSM employees (56\%). This Standard 6 means that the hospital embodies a safe, clean and healthy workplace/ service environment, and ensures the adequacy of facilities and infrastructure for clean and healthy living behavior. Indicators of the standard 6 that are of particular concern to achieve include "Hospital declared a nonsmoking area and strict and disciplined regulations applied" (56.7\%) and the "Hospital guarantees the implementation of Islamic values in the hospital environment"(57.3\%). The safety and health of employees have an ethical dimension because the decisions of the management of the hospital can affect the lives and welfare of their employees (Lin \& Lin, 2011). The Non-Smoking Area
Policy (KTR) and smoking behavior in the environment of Muhammadiyah businesses including Muhammadiyah Hospital have clear rules, meaning that the KTR is enforced and the forbidden "fatwa" of smoking exists and is enforced, but apparently is not discipline enough. This can adversely affect the health of employees and patients or visitors at Muhammadiyah Hospital. Islamic values are among the values that will support the creation of a healthy work culture and environment because they are linked to shared beliefs and values that interact with staff, systems and structures of the hospital to obtain healthy behavioral norms (Lin \& Lin, 2011).

\section{Conclusion}

Finally, this study certainly has several limitations. Even though the response rate is $100 \%$, the data obtained is in the form of selfassessment tools based on level of knowledge, attitudes and exposure of respondents with a very wide variation in $\mathrm{HPH}$, so that it may lead to large variations in the assessment of achievement of each HPH standard.

Overall, the Muhammadiyah Hospital (RSM) in DKI Jakarta has implemented Health Promotion in Hospital (HPH) efforts with fairly good achievements. Steps to increase the performance of $\mathrm{HPH}$ units in each RSM must be considered, especially the capacity building of members of the HPH unit, as well as the participation of RSM permanent employees in $\mathrm{HPH}$ and $\mathrm{HPH}$ training activities which are still considered low. HPH efforts are expected not to be limited to mere project objectives, need a comprehensive strategy that involves all parties, both with charitable units of Muhammadiyah and other sectors, business and other private sectors and RSM can involved the existing $\mathrm{HPH}$ national network.

\section{References}

Amiri, M., Khosravi, A., Riyahi, L., \& Naderi, S., 2016. The Impact of Setting the Standards of Health Promoting Hospitals on Hospital Indicators in Iran. PLoS ONE, 11(12), pp.112.

Baxter, R., Hastings, N., Law, A., \& Glass, E.J., 2008. The International Network of Healt Promoting Hospitala and Health Servives: Integrating Health Promotion Into Hospitals and Health Services. Concept, Framework and Organization. Animal Genetics, 39(5), 
pp.561-563.

Dilani, A., 2008. Psychosocially Supportive DesignAs a Theory and Model to Promote Health.

Groene, O., 2005. Evaluating the Progress of the Health Promoting Hospitals Initiative? A WHO perspective - Commentary on: Whitehead, D., 2004. The European Health Promoting Hospitals (HPH) project: How Far on?. Health Promotion International, 20(2), pp.205-207.

Groene, O., Alonso, J., \& Klazinga, N., 2010. Development and Validation of the WHO Self-Assessment Tool for Health Promotion in Hospitals: Results of a Study in 38 Hospitals in Eight Countries. Health Promotion International, 25(2), pp.221-9.

Hakim, L., BZ, H., \& Fauzi., 2013. Analisis Manajemen Dan Intervensi Bagi Pasien Terhadap Upaya Promosi Kesehatan Rumah Sakit (HPH) Di Rumah Sakit Umum Pusat Haji Adam Malik Medan Tahun 2012. Kebijakan, Promosi Kesehatan Dan Biostatistika, 2(1), pp.1-10.

Johansson, H., Weinehall, L., \& Emmelin, M., 2009. It Depends on What You Mean: A Qualitative Study of Swedish Health Professionals' Views on Health and Health Promotion. BMC Health Services Research, 9, pp.1-12.

Kemenkes RI., 2011. No Title Standar Promosi Kesehatan Rumah Sakit.

Lee, C.B., Chen, M.S., Chien, S.H., Pelikan, J.M., Wang, Y.W., \& Chu, C.M.Y., 2015. Strengthening Health Promotion in Hospitals with Capacity Building: A Taiwanese Case Study. Health Promotion International, 30(3), pp.625-36.

Lee, C.B., Chen, M.S., \& Wang, Y.W., 2014. Barriers to and Facilitators of the Implementation of Health Promoting Hospitals in Taiwan: A Top-down Movement in Need of Ground Support. International Journal of Health Planning and Management, 29(2), pp.197213.

Lin, Y.W., \& Lin, Y.Y., 2011. Health-Promoting Organization and Organizational Effectiveness of Health Promotion in Hospitals: A National Cross-sectional Survey in Taiwan. Health Promotion International, 26(3), pp.362-375.
McHugh, C., Robinson, A., \& Chesters, J., 2010. Health Promoting Health Services: A Review of the Evidence. Health Promotion International, 25(2), pp.230-237.

Nova, A., Purba, A., Bm, S., \& Shaluhiyah, Z., 2016. Pelaksanaan Kegiatan Promosi Kesehatan Rumah Sakit (HPH) di Rumah Sakit Bhayangkara Tingkat II Semarang. Jurnal Kesehatan Masyarakat, 4(4), pp.2356-3346.

Pelikan, J.M., 2012. Health Promoting Hospitals Assessing Developments in the Network. Italian Journal of Public Health, 4(4), pp.261270.

Poland, B., Krupa, G., \& Mccall, D., 2009. Settings for Health Promotion: An Analytic Framework to Guide Intervention Design and Implementation. Health Promotion Practice, 10(4), pp.505-516.

VHA., 2009. Health Promoting Health Services. The Victorian Heathcare Association.

Whitehead, D., 2004. The European Health Promoting Hospitals (HPH) Project. How Far on?. Health Promotion International, 19(2), pp.259-267.

Whitehead, D., 2005. Health Promoting Hospitals: The Role and Function of Nursing. Journal of Clinical Nursing, 14(1), pp.20-27.

Who European Office for Integrated Health Care Services. 2004. Standards for Health Promotion in Hospitals. Copenhagen.

Wieczorek, C.C., Marent, B., Osrecki, F., Dorner, T.E., \& Dür, W., 2015. Hospitals as Professional Organizations: Challenges for Reorientation Towards Health Promotion. Health Sociology Review, 24(2), pp.123-136.

Yaghoubi, M., \& Javadi, M., 2013. Health Promoting Hospitals in Iran: How it is. Journal of Education and Health Promotion, 2(1), pp.41. 